\title{
Water Quality in the Sagarmatha National Park, Nepal: A Modification of Viable Field-based Testing Methods
}

\author{
Joshua Gruver \\ Ball State University, United States \\ E-mail: jbgruver@bsu.edu
}

Kirsten Nicholson

Ball State University, United States

Klaus Neumann

Ball State University, United States

Subodh Sharma

Kathmandu University, Nepal

Carolyn Dowling

Ball State University, United States

Received: January 22, 2017 Accepted: February 6, 2017

doi:10.5296/emsd.v6i2.10635 URL: https://doi.org/10.5296/emsd.v6i2.10635

\begin{abstract}
Poorly managed solid waste disposal in the Sagarmatha National Park, Nepal, (SNP) is causing considerable degradation of major rivers and drinking water in the region. This research began as a study to: (1) identify sources of water contamination; (2) better understand the breadth of this problem; and (3) begin to develop technical solutions for resolving these problems. The remoteness of the study site and rugged terrain challenged the equipment used to collect and store samples and caused us to modify our protocols. Further, the complex interactions among natural resource management issues, increasing tourism, a
\end{abstract}


struggling economy, climate change, and the risk of natural disasters (e.g., earthquakes) in the SNP triggered a change in our initial approach to the problem. We decided to broaden our research goals to include community-based resource management efforts designed to inform how resources are protected and governed in the SNP. Understanding communities, residents, and other stakeholder's attitudes and perceptions of the social, economic, and environmental risks is necessary to help community leaders develop and sustain a useful governing framework to support water quality risk mitigation. This manuscript is an effort to communicate the evolving nature of our methodology over time and make a case for flexible research design, particularly in areas where geography, culture, and resource management potentially pose substantial challenges to traditional research methods. The methodology we eventually adopted is generalizable to similar remote mountainous regions around the globe.

Keywords: Drinking water, Fecal coliform, Nepal, human dimensions of resource management, Sagarmatha National Park, Tourism

\section{Introduction}

The combination of unrestricted tourism and the lack of waste management is resulting in the contamination of much of the surface and drinking water in the Sagarmatha National Park (SNP), Nepal (Ghimire et al., 2013a; Nicholson et al., 2014, 2016). Tourists, their porters and guides, and their concurrently generated refuse are causing aggressive anthropogenic pressure with serious environmental consequences to the SNP and SNP Buffer Zone ecosystems (Ghimire et al., 2013a). Open defecation and poorly managed solid waste disposal (sewage and toilet waste can be found piped into nearby streams and rivers (Carovello et al., 2007)) is causing considerable degradation of major rivers in the region (Ghimirie et al., 2013a,b) and drinking water (Nicholson et al., 2016).

Field work began in May 2014 to identify sources of water contamination, better understand the breadth of the problem, and to determine appropriate solutions and actions to address water quality and quantity issues. This article documents the numerous unexpected issues encountered during our field research, including challenging site characteristics (e.g., rugged and remote geography) and a catastrophic geological event (2015 earthquake) as well as the realization that solving the water contamination problem is not only related to proper waste disposal, sanitation, and drinking water treatment, but connected to how drinking water is protected and governed in this rural mountainous region (Figure 1). Because of these issues, our research methodology was forced to evolve. Through describing this process, we suggest the need for using open and adaptable approaches to research design, particularly in areas where geography, culture, and resource management can potentially pose significant challenges to traditional research methods. 


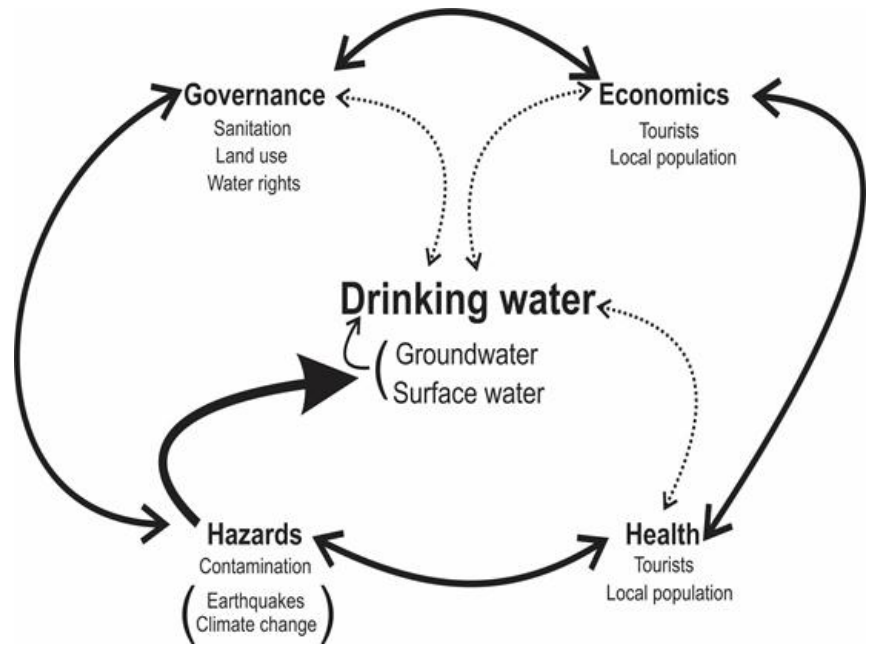

Figure 1. Illustration showing the relationships between contaminated drinking water, economics, governance, health and hazards in the SNP

\section{Background}

\subsection{Place and Tourism}

For most people the classic trek to Mt. Everest Base Camp (EBC) begins at the township of Lukla and extends beyond the township of Gorek Shep to EBC (Figure 2). The SNP was declared a World Natural Heritage Site in 1979 and is the highest altitude protected area in the world. The region has experienced a $100,000 \%$ increase in the number of tourists over the past 50 years: from 20 in 1964 to peak numbers of >32,000 in 2009 and 2010 (Salerno et al., 2013; Ghimirie et al., 2013a). Recent disasters in the region, such as the 2015 earthquake, caused a decrease in tourist numbers. 


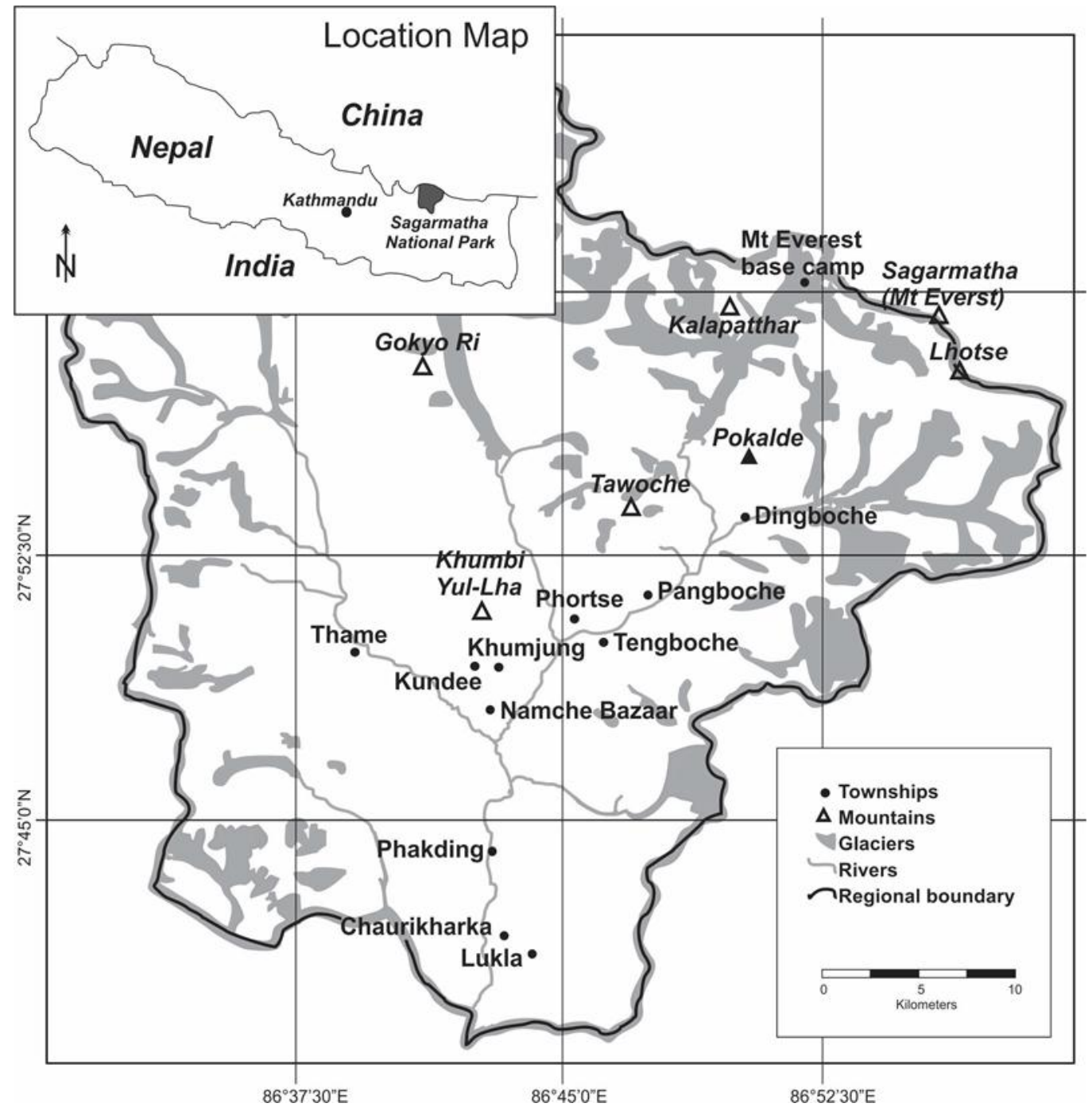

Figure 2. Sketch map the location of the SNP and SNP Buffer Zone, the Dudh Koshi drainage basin in Nepal (inset) and the location of major townships, rivers, glaciers and mountains within the area

Currently, there are approximately 6,000 people, primarily of the Sherpa ethnic group, living in the SNP and SNP Buffer Zone. Though agriculture is an important component of resident's lives, increased dependence on tourism has reshaped the local economy and social structure (Nepal 2000; Manfredi et al. 2010; Panzeri et al., 2013). While tourism has brought prosperity, it also resulted in significant changes to the Sherpa culture through a complex interplay of effects on lifestyle and livelihood practices, resource governance systems, development interventions, and technological innovations (Stevens 1996; Rogers et al 1998; Stevens 2003; Byers 2005; Ives 2005; Panzeri et al., 2013; Mukherji et al., 2015). Within the Sherpa community, there is much debate about how to develop a sustainable economy without exacerbating environmental and cultural degradation (Nyaupane et al. 2006).

Nepal's State of Environment Report (2000) identified water pollution as the most significant public health issue in the country, with much of the pollution load tied to human activities (e.g., domestic sewage) (Devotka and Neupane 1994; Manfredi et al. 2010). Previous studies 
by Ghimire et al. (2013) and Nicholson et al. (2016) began to track and characterize water contamination issues in the SNP, beginning with major rivers and streams and smaller, community and family owned drinking water sources, but none addressed the issues around governance and management.

\subsection{Water Contamination}

Recent studies of $E$. coli and coliform bacteria in the SNP were conducted by Ghimire et al. (2013a) and Nicholson et al. (2016); confirming earlier work from Caravello et al. (2007). Collectively, these studies concluded that all rivers contained E. coli and coliform bacteria. The work of Nicholson et al. (2016) showed similar trends in drinking water, whereby many drinking water sources were contaminated with E. coli and/or coliform bacteria and contamination rates increased with decreasing altitude. Finding that bacterial contamination increased from the higher altitude portion of the SNP to the lower altitude regions. The results indicate increased development in anthropogenic and socio-cultural activities in the lower stretch were responsible for the increased bacterial contamination. Further, shifts in climate and the associated changes in precipitation patterns and snowpack were also changing water availability in a clear and noticeable way (Alford and Armstrong 2010).

\subsection{Water Management and Governance}

Increasing competition for water resources, the impacts of climate change, tourism, and shifting water availability due to a wide variety of issues is driving the need globally to better coordinate water resources management. Integrated Water Resources Management (IWRM) is a process that encourages the coordinated development and management of water resources to maximize economic and social welfare without compromising ecosystem sustainability. The core principles of IWRM include integration, participation, decentralization, and water management according to hydrological boundaries (Global Water Partnership (GWP), 2000). With IWRM the management and decision-making power rests with the community. Community residents understand the socio-cultural and environmental context of place better than any outsider. Many developing country governments in Latin America, Asia, and Africa have incorporated IWRM as a guiding principle for their national water policy programs (Suhardiman, 2015).

IWRM however is not without its challenges. Most often the way IWRM has been implemented in past contexts has been the cause of significant problems (Biswas, 2004, 2008; Molle, 2008; Varis et al. 2008). Fundamental to this research will be what aspects should be integrated, how, and by whom. Identifying institutional barriers to IWRM application should be an early priority for research and outreach teams.As well, careful consideration must be given to making sure all sections of society are included and represented in any decision/management effort. The onus of managing SNPs drinking water quality, and of managing sewage and waste, has devolved from the national government to citizens and communities across Nepal, including the SNP and SNP Buffer Zone. The first Park Management Plan was implemented in 1976 (Garratt 1981), giving the state control of many resources and largely centralized tourism revenues. However, the national government struggled to support, maintain, and monitor environmental standards (Suhardiman et al., 
2015). Thus, in 2002, the Buffer Zone Policy was created to increase community-based management of resources and allocated $30-50 \%$ of park revenues for investment in local development.

Toward implementation of IWRM and community-based management in the SNP, the recently redeveloped Park Management Plan (Department of National Parks and Wildlife Conservation (DNPWC) 2005, 2006) emphasizes community self-governance, and support of local economic development, including local stewardship of natural resources (primarily forests), the growth of a self-regulated tourism industry, local natural resource production systems (such as hydroelectric generation), and a multi-stakeholder governance system (Daconto and Sherpa, 2010). Shortly after the adoption of this new plan, Daconto and Sherpa (2007) met with Sherpa community leaders, DNPWC staff, and SNP Buffer Zone Committee members to identify topics of key interest regarding the future of the SNP. Key issues identified for long-term strategic analysis included: tourism management, changes in the agro-pastoral economy, and linking research and learning through adaptive park management. Of major importance to SNP stakeholders were the impacts of tourism. As well, they identified the need to develop and support self-regulation and governance of both tourism and natural resources.

\section{Unexpected Challenges and Evolving Methodology}

During our first visits to SNP we used the EPA approved field-testing methods for E.coli and coliform bacteria (Nicholson et al. 2016). Sites were selected based on drinking water availability for local populations and tourists. Samples were collected in sterile $100 \mathrm{~mL}$ Whirl-pak bags containing a non-nutritive pill with $10 \mathrm{mg}$ sodium thiosulfate and kept at temperatures below $20^{\circ} \mathrm{C}$ prior to analyses. Analysis of fecal coliform followed the EPA approved method 9222D in Standard Methods (APHA, 1998) by using a standard Hach® portable water test kit. Samples were filtered in temporary facilities using a vacuum pump to filter sample through sterile 0.45 micron filter, placed into a petri dish treated with Hach ${ }^{\circledR}$ $\mathrm{m}$-ColiBlue24® broth medium and placed in a $\mathrm{Hach} \circledast$ portable field incubator at $35^{\circ} \mathrm{C} \pm$ $0.5^{\circ} \mathrm{C}$ for 24 hours. Sample counts were done quantitatively, in duplicate, using a magnifying glass.

Unfortunately, employing these methods proved inappropriate for a variety of reasons. For example, in 2014 we used a helicopter to bring a generator, fuel, and six rechargeable $12 \mathrm{~V}$ batteries to the field area, all of which were carried by porters for the remainder of the trip $(>100 \mathrm{~kg})$. However, it was impossible to keep the incubator within $\pm 0.5^{\circ} \mathrm{C}$ because of fluctuations in air temperature and because we moved every second day. The generator had to be watched continuously and the batteries would not hold their charge due to the extreme cold. Essentially, we discovered it was not possible to meet the EPA standards of maintaining $35^{\circ} \mathrm{C} \pm 0.5^{\circ} \mathrm{C}$ for 24 hours.

Further, the EPA approved test kits proved difficult to use in a true "field" based setting. In order to filter samples we had to set up a temporary laboratory. Tourists often complained about laboratory facilities in the teahouse dining rooms, hence we were occasionally limited to a windowsill or flat ground surface outdoors. Another complication occurred as the 
Whirl-pak bags often leaked when carried by backpack, potentially causing cross contamination such that samples were discarded. In addition the test kits alone added an additional $30 \mathrm{~kg}$ of supplies, which, importantly, generated a similar amount of waste that was carried throughout the trip and returned via airplane to Kathmandu for disposal.

Late in 2014 we began testing other fecal coliform test kits and settled on those produced through Micrology Labs®. These test kits were field useable, lightweight, and generated less waste. Samples were filtered directly onsite, using a lightweight plastic filter rinsed with DI water, and sterile 0.45 micron filters. The filters were placed in a petri dish, Coliscan ${ }^{\circledR} \mathrm{MF}$ medium was added, the petri dishes were sealed with Parafilm ${ }^{\circledR}$ and placed in a small insulated cooler bag. In 2016 we tested and adopted pre-treated test cards produced by Micrology Labs®. The test cards are even easier to use as they already contain the Coliscan® MF medium. The filtration method remains the same, but now the filters are placed onto the test cards, each test card is placed into a sealed plastic bag (to eliminate possible cross contamination) and placed into the incubator. Coliscan ${ }^{\circledR}$ MF medium (manufactured by Micrology Laboratories LLC) is a nutrient liquid formulation containing a growth medium that includes color producing enzyme substrates specific for the target organisms (E. coli and other coliforms), such that these organisms grow as differently colored colonies that are easily differentiated. And, we now used a small, insulated cooler to incubate the samples. By placing 2-6 hand warmers (commercially mass produced) wrapped in a small towel inside the cooler we could maintain temperatures over $16^{\circ} \mathrm{C}$ for over $24-48$ hours. This was warm enough to allow bacterial growth. This new method may not meet approved EPA standards but it was easy, effective, and can be used successfully when there is no power or vehicular access to the study area.

\subsection{Earthquake}

In April 2015, a magnitude 7.8 earthquake occurred approximately $80 \mathrm{~km}$ northeast of Kathmandu (USGS). Since the initial earthquake, the region has experienced over 100 aftershocks greater than magnitude 2.5 (USGS). Personal communication with people living in the SNP suggested many springs were affected by the earthquake and subsequent aftershocks. The earthquake activity further complicated the conflicting interests between the need for economic growth, through tourism, and the ability of current infrastructure to handle human waste disposal. As a result, our focus on the characterization of water contamination shifted to include basic water access, availability, and management.

Our original research goal was to determine the effects of human waste on surface and groundwater, as well, to determine the contribution of glacial melt waters to surface and groundwater. However, the effects of the earthquake on Nepal's physical, social, and political systems and our realization that maintaining a sustainable and accessible supply of drinking water for everyone required us to consider how water was being managed and to make sure all community members had a voice in the process. Toward this end, we brought on two new team members - a human dimensions specialist and education specialist. Our project goals shifted to include strategies to:

- Enhance local governance: Develop a land-use, water-use, and sanitation governance 
framework that stakeholders created and were able to continue after this project.

- Enhance education and outreach: Develop methods/practices to help educate the populace and tourists as to the importance of land, water, sanitation rights and privileges.

With this new focus we felt it essential to better understand the contextual factors informing current water management practices. As park management is increasingly decentralized, the SNP community's ability to adapt and address long-term challenges, such as access to potable water, will become more dependent on governance and local resource management. Frameworks that allow the public and other community actors to play an integral part of the development and operation of the process are gaining popularity in Nepal (Acharya 2005; Suhardiman et al., 2015)). A collaborative and participatory design is needed to achieve a regional balance among local and extra local needs and interests as they relate to tourism development, sustainable land-use management, and regional economic viability (Solerno et al. 2010).

Our data collection methods will focus on Key Informant (KI) interviews, household interviews, and community facilitated dialogue throughout the four largest towns in the region. Each method will reflect an inclusive dialogue to assess public perceptions, attitudes and beliefs and promote learning about and understanding environmental issues faced in the SNP. In this manner we hope to be inclusive of underrepresented groups and form a more completed view of community perspectives (Gaventa 1980; Luloff and Swanson 1995).

Our plan to engage the community in discussions of water management and governance will take place over a three year time period. Year 1 will focus on interviewing KIs concerning:(1) the impacts of tourism in their respective community; (2) values and perspectives concerning water quality, water access, and sanitation; (3) ideas about significant areas to be conserved; and (4) ideas on what they think would work to protect the long-term integrity of the region. KIs are community leaders, Park Management Board employees, local politicians, business owners, long term residents, individuals working in water supply and waste removal. KI interviews will serve to better contextualize our understanding of water quality and waste management issues in the SNP and the social realities that govern community engagement and activeness there.

During years 2 and 3 we will continue to collect KI data until we reach data saturation (15-20 $\mathrm{KI}$ interviews per large town and areas proximate) (Elmendorf and Luloff 2001). As well, we will expand communication with households, teahouse owners, tourists and more through interviews to capture regular citizen's perspectives and broaden our understanding of the contextual factors influencing water quality and waste issues in SNP.

Year 3 we will host four facilitated community dialogue sessions (in each of the four largest towns) with the purpose of gaining broader input. We will invite all stakeholders (i.e., KI and household interviewees, community leaders, teahouse owners, and residents) to facilitated community dialogue sessions and share what we've learned from KI and household interviews, as well as other parts of the project (e.g., water sampling). Input from the KIs and 
household surveys will be critical in framing discussion questions and creating a context for interacting with stakeholders to pick up on new and/or additional data that was missed during the interview phase, but to also assess general citizen concerns about the SNP and how communities and others might address issues related to water quality, waste, and tourism.

Group discussions at these meetings will focus on broad parameters of concern and act as the springboard for conversation with and among those in attendance. These discussions will assess general citizen-stakeholder concerns about water and sanitation in the SNP and how communities and others might address them. The objectives of each facilitated community dialogue are to: (1) assess stakeholder willingness to be involved in activities designed to maintain and enhance quality of life; (2) help identify ways to move forward; and (3) develop strategies to begin to collectively manage and govern water resources and waste, and appropriate tourist education about these issues.

Using interviews, surveys, community dialogues, and group activities, we hope to help local residents establish a regional Land and Water Conservation Council. This council will begin to develop land, water, and sanitation education strategies. This process will help ensure inclusion of the local communities in land-use and water quality decision making, increase transparency in processes related to water use and waste disposal, and make use of a shared vision based on a co-developed framework.

\section{Conclusions}

This article highlights two methodological modifications to our research regarding water quality in the NSP, Nepal. First, the difficult terrain and the physical remoteness of the study area demanded modify modification of extant EPA protocols to find appropriately sized fecal coliform test kits that were less cumbersome and did not produce excessive wastes. As well, despite EPA protocol, we abandoned the use of incubators. Instead, we employed hand warmers in small, insulated coolers, which produced similar and accurate results.

Second, the 2015 earthquake shifted our approach to solving water quality issues. For example, many water sources dried up because of the earthquake and new ones become available. Instead of just focusing on drinking water quality, the immediate need was to engage Nepalese communities in the SNP on water management, governance, and education and how they can be active participants in how this is done. This new focus was important as drinking water access and rules surrounding how drinking water is governed are, and will continue to be, important for resident's and tourist's well-being.

The ideas presented here suggest the realities of site characteristic (i.e., rugged terrain, remoteness, and unexpected geomorphological events) having a significant impact on research goals and objectives. In our case, it became necessary to change the field testing procedures we were following. As well, to consider more deeply the drinking water needs of SNP residents in the aftermath of the earthquake, and how we can help address those needs in an inclusive and collaborative way. We hope this narrative provides some modicum of confidence for others engaging in research in areas that have high proclivity to shifting biophysical and/or socio-cultural contexts, that shifting research priorities and focus do not 
need to be the death of a project, but can open the door to other ways of engaging people, communities, and the resource risks they face.

\section{Acknowledgement}

The authors would like to thank the following people and organizations for their support: Troy Risk Inc. (Indianapolis), Indiana Geologists, Ball State University, Ang Norbu Sherpa (Holiday Namche), Ang Pema Sherpa (Valley View Khumjung) and the Sagarmatha National Park Service.

\section{References}

Acharya, K. P. (2005). Private, collective, and centralized institutional arrangements for managing forest "Commons" in Nepal. Mountain Research and Development, 25(3), 269-277. https://dx.doi.org/10.1659/0276-4741(2005)025[0269:PCACIA]2.0.CO;2

Alford, D., \& Armstrong, R. (2010). The role of glaciers in stream flow from the Nepal Himalaya, The Cryosphere Discussions, 4, 469-494.

Biswas, A. K. (2004). Integrated water resources management: a reassessment: a water forum contribution. Water international, 29(2), 248-256.

http://dx.doi.org/10.1080/02508060408691775

Biswas, A. K. (2008). Integrated water resources management: Is it working? International Journal of Water Resources Development, 24(1), 5-22.

http://dx.doi.org/10.1080/07900620701871718

Byers A. (2005). Contemporary human impacts on alpine ecosystems in the Sagarmatha (Mt Everest) National Park, Khumbu, Nepal. Annals of the Association of American Geographers, 95(1), 112-140. http://dx.doi.org/10.1111/j.1467-8306.2005.00452.x

Caravello, G. U., Boselli, A. M., Bertollo, P., \& Baroni, A., (2007). Assessing Ecosystem Health: An Analysis of Tourism Related Change and Impact in Khumbu Valley, International Journal of Ecology, 14, 45-64.

Chhatre, A., \& Agrawal, A. (2009). Trade-offs and synergies between carbon storage and livelihood benefits from forest commons. Proceedings of the national Academy of sciences, 106(42), 17667-17670. http://dx.doi.org/10.1073/pnas.0905308106

Daconto, G., \& Sherpa, L. N. (2007). Exploring the future: Analysis of Future Scenarios for Tourism Development in Sagarmatha National Park and Buffer Zone, Report on first Scenario Planning Exercise. Kathmandu: HKKH Partnership Project, Technical paper.

Daconto, G., \& Sherpa, LN. (2010). Applying Scenario Planning to Park and Tourism Management in Sagarmatha National Park, Khumbu, Nepal. Mountain Research and Development, 30(2), 103-112. http://dx.doi.org/10.1659/MRD-JOURNAL-D-09-00047.1

Devkota, S. R., \& Neupane, C. (1994). Industrial Pollution Inventory of Nepal, Industrial Pollution Control Management Project UNDP/UNIDO/MOI/NEP/91-029. Kathmandu. https://doi.org/10.1016/S0921-8009(98)00034-2 
DNPWC [Department of National Parks and Wildlife Conservation]. (2005). Sagarmatha National Park and Buffer Zone Management Plan. Kathmandu, Nepal: DNPWC.

DNPWC [Department of National Parks and Wildlife Conservation]. (2006). Sagarmatha National Park Management and Tourism Plan 2006-2011. Kathmandu, Nepal: DNPWC.

Elmendorf, William, F., \& Lulloff, A. E. (2001). Using Qualitative Data Collection Methods When Planning for Community Forests. Journal of Arboriculture, 27(3), 139-151.

Garratt, K. J. (1981). Sagarmatha National Park Management Plan. Wellington, New Zealand: Department of Lands and Survey.

Gaventa, J. (1980). Power and powerlessness. Urbana: University of Illinois Press, 36, 1-27.

Ghimirie, N. P., Jha, P. K., \& Caravello, G., (2013a). Physico-Chemical Parameters of High-Altitude Rivers in the Sagarmatha (Everest) National Park, Nepal, Journal of Water Resource and Protection, 5, 761-767. https://doi.org/10.4236/jwarp.2013.58077

Ghimirie, N. P., Jha, P. K., \& Caravello, G., (2013b). Water Quality of High-Altitude Lakes in the Sagarmatha (Everest) National Park, Nepal, Journal of Environmental Protection, 4, 22-28. https://doi.org/10.4236/jep.2013.47A003

GWP, G. W. P. (2000). Integrated water resources management. TAC Background Papers, (4).

Ives, J. D. (2005). Himalayan delusions: Who's kidding who and why-Science at the service of media, politics and the development agencies. Himalayan Journal of Sciences, 3(5), 15-24. http://dx.doi.org/10.3126/hjs.v3i5.457

Kathmandu, N. STATE OF THE ENVIRONMENT. (2000).

Luloff, A. E., \& Swanson, L. E. (1995). Community agency and disaffection: enhancing collective resources. Investing in people: The human capital needs of rural America, 351-372.

Manfredi, E. C., Flury, B., Viviano, G., Thakuri, S., Khanal, S. N., Jha, P. K., \& Ghimire, N. P. (2010). Solid waste and water quality management models for SagarmathaNational Park and Buffer Zone, Nepal: implementation of a participatory modeling framework. Mountain Research and Development, 30(2), 127-142.

https://doi.org/10.1659/MRD-JOURNAL-D-10-00028.1

Molle, F. (2008). Nirvana concepts, storylines and policy models: Insights from the water sector. Water alternatives, 1(1), 131.

Nepal, S. K. (2002). Involving indigenous peoples in protected area management: Comparative perspectives from Nepal, Thailand, and China. Environmental Management, 30(6), 0748-0763. https://doi.org/10.1007/s00267-002-2710-y

Nicholson, K. N., Neumann, K., Dowling, C., \& Hayes, E. (2014). Coliform Bacteria and E.coli In Waterways Between Lukla And Namche Baazar, Nepal. International Water Association Conference, Nepal. 


\section{Macrothink}

Environmental Management and Sustainable Development

ISSN 2164-7682

2017, Vol. 6, No. 2

Nicholson, K., Hayes, E., Neumann, K., Dowling, C., \& Sharma, S. (2016). Drinking Water Quality in the Sagarmatha National Park, Nepal. Journal of Geoscience and Environment Protection, 4(04), 43. https://doi.org/10.4236/gep.2016.44007

Nyaupane, G. P., Morais, D. B., \& Dowler, L. (2006). The role of community involvement and number/type of visitors on tourism impacts: A controlled comparison of Annapurna, Nepal and Northwest Yunnan, China. Tourism management, 27(6), 1373-1385.

https://doi.org/10.1016/j.tourman.2005.12.013

Persha, L., Agrawal, A., \& Chhatre, A. (2011). Social and ecological synergy: local rulemaking, forest livelihoods, and biodiversity conservation. Science, 331(6024), 1606-1608. https://doi.org/10.1126/science.1199343

Rogers, P., Aitchison, J., \& Lucas, B. (1998). Sustainable Tourism in the Sagarmatha National Park and the Solu-Khumbu District. A final report of the seminar convened at the British Council on 12 August 1998. Aberystwyth, Wales, United Kingdom: International Centre for Protected Landscapes, University of Wales.

Salerno, F., Viviano, G., Manfredi, E. C., Caroli, P., Thakuri, S., \& Tartari, G. (2013). Multiple Carrying Capacities from a management-oriented perspective to operationalize sustainable tourism in protected areas, Journal of Environmental Management, 128, 116-125. https://doi.org/10.1016/j.jenvman.2013.04.043

Stevens, S. F. (1996). Claiming the High Ground: Sherpas, Subsistence and Environmental Change in the Highest Himalayas. Delhi, India: Motilal Banarsidass.

Stevens, S. F. (2003). Tourism and deforestation in the Mt Everest region of Nepal. The Geographical Journal, 169(3), 255-277. https://doi.org/10.1111/1475-4959.00089

Suhardiman, D., Clement, F., \& Bharati, L. (2015). Integrated water resources management in Nepal: key stakeholders' perceptions and lessons learned. International journal of water resources development, 31(2), 284-300.

Varis, O., Rahaman, M. M., \& Stucki, V. (2008). The rocky road from integrated plans to implementation: Lessons learned from the Mekong and Senegal River basins. International Journal of Water Resources Development, 24(1), 103-121.

http://dx.doi.org/10.1080/07900620701723307

\section{Copyright Disclaimer}

Copyright for this article is retained by the author(s), with first publication rights granted to the journal.

This is an open-access article distributed under the terms and conditions of the Creative Commons Attribution license (http://creativecommons.org/licenses/by/3.0/). 